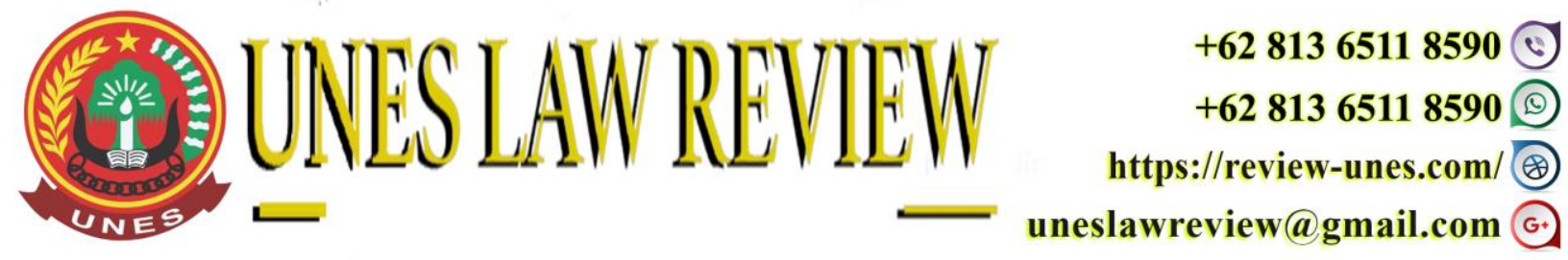

DOI: https://doi.org/10.31933/unesrev.v3i4

Diterima: 03/06/2021, Diperbaiki: 20/06/2021, Diterbitkan: 03/07/2021

\title{
PELAKSANAAN PENGAWASAN TERHADAP PEJABAT PEMBUAT AKTA TANAH OLEH KEPALA KANTOR PERTANAHAN KOTA PADANG
}

\author{
Silvia Septriana \\ Kantor Pertanahan Kota Padang, Indonesia \\ Email: silviaseptriana140986@yahoo.co.id
}

Corresponding Author: Silvia

ABSTRACT

The Head of the Land Office supervises PPAT as stipulated in the provisions of the Regulation of the Minister of Agrarian affairs and Spatial Planning / Head of the National Land Agency of the Republic of Indonesia Number 2 Year 2018 concerning the Development and Supervision of Land Deed Officials, article 65 of the Regulation of the Head of the National Land Agency No. 1 of 2006 concerning the implementation provisions of Government Regulation No. 37 of 1998 concerning Land Deed Officials. However, in the practice of PPAT carrying out the task is in accordance with the rules or not in accordance with the rules that have been determined the application of the regulation that is not in accordance with the conditions of the field, because the sanctions have not been enforced so that violations occur, one of which is the unreported monthly report of PPAT to the Head of Padang City Land Office.

Keywords: Supervision, PPAT, Padang City Land Office

\begin{abstract}
ABSTRAK
Kepala Kantor Pertanahan melakukan pengawasan terhadap PPAT sebagaimana diatur pada ketentuan Peraturan Menteri Agraria dan Tata Ruang/Kepala Badan Pertanahan Nasional Republik Indonesia Nomor 2 Tahun 2018 tentang Pembinaan dan Pengawasan Pejabat Pembuat Akta Tanah, pasal 65 peraturan Kepala Badan Pertanahan Nasional No. 1 Tahun 2006 tentang ketentuan pelaksanaan Peraturan Pemerintah Nomor 37 Tahun 1998 tentang Pejabat Pembuat Akta Tanah. Akan tetapi dalam praktek PPAT melaksanakan tugas sudah sesuai dengan aturan atuau tidak sesuai dengan aturan yang telah ditetapkan penerapan peraturan tersebut yang tidak sesuai dengan kondisi lapangan, karena tidak ditegakkannya sanksi yang telah ditetapkan sehingga terjadilah pelanggaran-pelanggaran yang salah satunya adalah tidak dilaporkannya laporan bulanan PPAT kepada Kepala Kantor Pertanahan Kota Padang.
\end{abstract}

Kata Kunci: Pengawasan, PPAT, Kantor Pertanahan Kota Padang 


\section{PENDAHULUAN}

Tugas menyelenggarakan pendaftaran tanah diseluruh wilayah Indonesia diselenggarakan oleh Badan Pertanahan Nasioanal yang tugas pelaksanaannya menjadi tanggung jawab Kepala Kantor Pertanahan. Kepala Kantor Pertanahan dalam melaksanakan kewenangannya untuk pelaksanaan pendaftaran tanah dibantu oleh Pejabat pembuat Akta Tanah (PPAT) dan pejabat lainnya yaitu panitia ajudikasi dan pejabat lelang. ${ }^{1}$

PPAT adalah Pejabat Umum4 hal ini di sebabkan karena PPAT, diangkat dan diberhentikan oleh Menteri Agraria dan Tata Ruang. PPAT memiliki tugas yaitu membantu Kepala Kantor Pertanahan dalam menjalankan pendaftaran tanah dengan diberi kewenangan untuk membuat Akta Otentik mengenai tindakan hukum tertentu yang berhubungan dengan kepemilikan atas tanah, kepemilikan satuan rumah susun, dan hak yang membebaninya

PPAT dalam melaksanakan kewenangannya,tidak luput dari kewajiban-kewajiban yang harus ditaati. kewajiban PPAT yang harus ditaati salah satunya adalah kewajiban PPAT untuk menyampaikan laporan bulanan mengenai akta yang dibuatnya yang diambil dari buku daftar akta PPAT kepada Kepala Kantor pertanahan selambat-lambatnya tanggal 10 bulan berikutnya. ${ }^{2}$

Terhadap pemberian kewenangan membuat akta peralihan hak atas tanah kepada PPAT untuk membantu Kepala Kantor Pertanahan dalam tugas melaksanakan pendaftaran tanah maka sudah sepantasnya ada pembinaan dan pengawasan terhadap tugas PPAT, pelaksanaan pembinaan dan pengawasan terhadap PPAT yang dilakukan oleh Kepala Kantor Petanahan diatur dalam Peraturan Menteri Negara Agraria Nomor 2 Tahun 2018 tentang Pengawasan dan Pembinaan Pejabat Pembuat Akta Tanah.

Pembinaan dan pengawasan yang dilakukan oleh Kantor Pertanahan terhadap PPAT, juga dilaksanakan oleh Kantor Pertanahan Kota Padang. Pada prinsipnya pembinaan dan pengawasan Kantor Pertanahan Kota Padang terhadap para PPAT merujuk kepada pertauran yang mengatur tentang PPAT, selain pertauran tentang PPAT, petunjuk Kepala Badan Pertanahan Nasional Republik Indonesia juga menjadi acuan yang utama bagi Kantor Pertanahan dalam melakukan pembinaan dan pengawasan terhadap PPAT yang ada di Kota Padang, dilakukan dengan prinsip kesinambungan dan konsisten, dengan tujuan utama mengawasi PPAT di dalam menjalankan tugasnya agar selalu berpegang teguh kepada peraturan -peraturan yang ada.

Pembinaan dan pengawasan terhadap para PPAT di seluruh Kabupaten/Kota mungkin secara teknis mempunyai beberapa perbedaan kecil. Perbedaan tersebut merupakan suatu hal yang wajar, dikarenakan teknis kegiatan pembinaan dan pengawasan terhadap para PPAT, melihat kebijaksanaan dari Kepala Kantor Pertanahan dari setiap Kabupaten/Kota. Oleh karena itu, menjadi sebuah hal yang menarik mengenai ruang lingkup dan cakupan pembinaan dan pengawasan yang dilakukan oleh Kantor Pertanahan Kota Padang terhadap PPAT di Kota Padang. Sehingga dirasa perlu untuk diangkat suatu penelitian yang khusus membahas, mengkaji serta menganalisis tentang pembinaan dan pengawasan Kantor Pertanahan Kota Padang terhadap para PPAT di Kota Padang.

\footnotetext{
${ }^{1}$ Peraturan Pemerintah Nomor 24 Tahun 1997 tentang Pendaftaran Tanah

${ }^{2}$ Peraturan Kepala Badan Pertanahan Nasional Nomor 1 Tahun 2006 tentang Pejabat Pembuat Akta Tanah
} 
Berdasarkan latar belakang tersebut, maka penulis mengemukakan permasalahan yang diteliti lebih lanjut dalam penulisan ini sebagai berikut :

1. Bagaimana dampak pembinaan dan pengawasan terhadap Pejabat Pembuat Akta Tanah (PPAT) Kota Padang oleh pejabat pada Kantor Pertanahan Kota Padang?

2. Apa hambatan dan upaya dalam penerapan fungsi pembinaan dan pengawasan Pejabat Pembuat Akta Tanah (PPAT) Kota Padang oleh pejabat pada Kantor Pertanahan Kota Padang?

\section{METODE PENELITIAN}

Penelitian ini menggunakan jenis penilitian yuridis empiris, penelitian yuridis empiris adalah penelitian hukum mengenai permberlakukan atau implementasi ketentuan hukum normatif secara in action pada setiap peristiwa hukum tertentu yang terjadi dalam masyarakat. ${ }^{3}$

Analisis dimaksudkan berdasarkan gambaran, adalah fakta yang diperoleh akan dilakukan analisis secara cermat untuk menjawab permasalahan. Analisis data yang di gunakan merupakan analisis data kualitatif yaitu data yang bersumber dari data berupa dokumen yang diperoleh secara lengkap, selanjutnya dianalisis dengan peraturan yang berkaitan dengan masalah yang diteliti, dengan menarik kesimpulan secara deduktif yang berkaitan dengan pembinaan dan pengawasan Pejabat Pembuat Akta Tanah (PPAT) di kota Padang oleh Kantor Pertanahan Kota Padang sedangkan sifat penelitian ini adalah deskriptif analitis yaitu menggambarkan atau mendeskripsikan fakta-fakta dengan penerapan tersebut secara analitis dan sistematis.

\section{HASIL DAN PEMBAHASAN}

\section{Pengawasan dan Pembinaan Kepala Kantor Pertanahan Terhadap Pejabat Pembuat Akta Tanah di Kota Padang}

Kantor Pertanahan Kota Padang mempunyai tugas pengawasan dan pembinaan terhadap PPAT sesuai dengan ketentuan pada Peraturan Menteri Agraria dan Tata Ruang/Kepala Badan Pertanahan Nasional Nomor 2 Tahun 2018 tentang Pembinaan dan Pengawasan Pejabat Pembuat Akta Tanah agar dalam melaksanakan jabatannya sesuai dengan ketentuan yang berlaku. Salah satu tugas dalam melaksanakan pembinaan dan pengawasan adalah membantu menyampaikan dan menjelaskan kebijakan dan peraturan serta petunjuk teknis pelaksanaan tugas PPAT yang telah ditetapkan dan peraturan perundang-undangan yang telah ditetapkan sebagai pedoman PPAT menjalankan tugas-tugasnya agar tidak terjadi ha-hal yang tidak diinginkan sehingga dapat menimbulkan kerugian banyak pihak. Hal ini dikarenakan banyak kasus yang terjadi akibat tidak ditaatinya peraturan-peraturan yang telah ditetapkan. Semua dikarenakan tidak berjalannya pembinaan dan pengawasan sebagaimana mestinya sehingga terkesan kurang optimalnya Kepala Kantor Pertanahan Kota Padang dalam mengawasi PPAT. Salah satu contoh kasus yang ditemui peneliti adalah tidak tertibnya PPAT dalam menyampaikan laporan bulanan dan masih banyak

\footnotetext{
${ }^{3}$ Abdulkadir Muhammad, Hukum dan Penelitin Hukum, Citra Aditya Bakti, Bandung, 2004, hlm.134
} 
PPAT yang terlambat menyampaikan atau mendaftarkan akta-akta yang telah mereka buat ke Kantor Pertanahan Kota Padang.

Dalam hal kewajiban PPAT menyampaikan laporan paling lambat setiap tanggal 10 (sepuluh) tiap bulannya, peneliti menemui lebih kurang 30\% PPAT terlambat manyampaikan laporan dan lebih kurang $5 \%$ PPAT yang tidak menyampaikan laporan padan bulan berjalan atau dengan kata lain menyampaikan laporan yang digabung dengan bulan berikutnya.

Mengenai penyampaian atau mendaftarkan akta-akta yang dibuat oleh PPAT, peneliti menemui untuk layanan Hak Tanggungan telah 100\% sesuai ketentuan yang berlaku, akan tetapi terhadap akta peralihan hak seperti akta jual beli, akta hibah, akta pembagian hak bersama dan akta lainnya terdapat $80 \%$ keterlambatan PPAT dalam penyampaian atau mendaftarkan akta tersebut pada Loket Pelayanan Kantor Pertanahan Kota Padang.

Kepala Kantor Pertanahan juga mempunyai kewenangan untuk memeriksa akta yang dibuat PPAT dan PPAT wajib melaporkannya secara periodik paling lambat tanggal 10 (sepuluh) setiap bulannya ke Kantor Pertanahan. Dari hasil penelitian, terdapat adanya PPAT yang terlambat dalam penyampaian laporan periodeik setiap bulannya dan ada juga yang alpa dalam penyampaian laporan bulanan tersebut. Terhadap PPAT yang terlambat dan tidak menyampaikan laporan bulanan, Kantor Pertanahan Kota Padang telah melakukan peneguran secara tertulis kepada PPAT yang tidak menjalankan kewajibannya tersebut. Akan tetapi ada beberapa PPAT yang telah ditegur secara tertulis sebanyak 2 (dua) kali dalam kealpaan penyampaian laporan bulanan dan tidak mengindahkan teguran tersebut. Hal ini dimungkinkan terjadi dikarenakan kurang tegasnya Kantor Pertanahan Kota Padang dalam memberikan sanki terhadap PPAT wilayah kerja Kota Padang. Karena berdasarkan lampiran Peraturan Menteri Agraria dan Tata Ruang/Kepala Badan Pertanahan Nasional Nomor 2 Tahun 2018 tentang Pembinaan dan Pengawsan Pejabat Pembuat Akta Tanah telah diatur bahwa apabila PPAT tidka menyampaikan laporan bulanan mengenai akta yang dibuatnya kepada Kantor Pertanahan dan kantor-kantor lain sesuai ketenteuan peraturan perundang-undangan yang berlaku selambat-lambatnya tanggal 10 bulan berikutnya maka dikenakan sanksi pemberhentian sementara paling lama 3 (tiga) bulan.Sampai dengan saat peneliti melakukan penelitian, Kantor Pertanahan belum pernah melakukan pemberhentian sementara terhadap PPAT yang melekukan pelanggaran dalam penyampaian laporan bulanan ini.

Pelanggaran lainnya yang dilakukan PPAT adalah tidak menyampaikan akta yang dibuatnya berikut dokumen yang bersangkutan kepada Kantor Pertanahan dalam waktu 7 (tujuh) hari kerja sejak ditandatangani akta yang bersangkutan. Terhadap pelanggaran ini Kantor Pertanahan telah beberapa kali melakukan teguran tertulis kepada PPAT yang melanggar. Akan tetapi teguran tertulis ini baru sebatas untuk terlambatnya menyampaikan Akta Pemberian Hak Tanggungan, terhadap akta peralihan hak Kantor Pertanahan Kota Padang belum pernah melakukan teguran atau pemberian sanksi terhadap PPAT.

Salah satu kasus yang ada di Kantor Pertanahan Kota Padang terkait terlambatnya menyampaikan akta sehingga berakibat dirugikannya beberapa pihak adalah persoalan tentang peralihan hak yang didaftarkan lebih dari 7 (tujuh) hari setelah di tandatanganinya akta oleh para 
pihak. Ketika peralihan hak didaftarkan terdapat pemblokiran dari pihak yang merasa dirugikan sehingga akta yang telah dibuat oleh PPAT tidak dapat diproses. Peristiwa ini persisnya terjadi pada peristiwa peralihan hak jual beli terhadap Sertipikat Hak Milik No. 4144 yang terletak di Kelurahan Gunung Sarik Kecamatan Kuranji Kota Padang, di mana objek tercatat atas nama Alizar (MKW) Cs yang akan dialihkan ke atas nama Asep Yuanda selaku pembeli. Dalam pelaksanaannya, PPAT telah melakukan pengecekan Sertipikat sesuai dengan amanah Pasal 97 Peraturan Kepala Badan Pertanahan Nasional Nomor 3 Tahun 1997 tentang Peraturan Pelaksanaan Peraturan Pemerintah Nomor 24 Tahun 1997 tentang Pendaftaran Tanah pada tanggal 09 November 2018 dan kemudian ditindak lanjuti dengan pembuatan Akta Jual Beli tanggal 09 Mei 2019 dan setelahnya didaftarkan ke Kantor Pertanahan pada tanggal 11 Juni 2019. Dalam hal ini terlihat jelas bahwa adanya beberapa kelalaian dari PPAT dalam melaksanakan kegiatan pendaftaran peralihan haknya.

Permasalahan lain pun timbul pada saat Akta Jual Beli yang dibuat oleh PPAT di daftarkan ke Kantor Pertanahan, yang ternyata telah terdapat catatan pemblokiran/keberatan dari pihak lain terhadap proses peralihan hak yang akan dilakukan sehingga pencatatan terhadap peralihan hak tersebut tidak dapat dilaksanakan. Permasalahan-permasalahan tersebut di atas sangat merugikan kepada calon pemegang hak/pembeli karena objek yang telah dibelinya tidak dapat dialihkan ke atas namanya di Kantor Pertanahan Kota Padang. Dan permasalahan ini juga menimbulkan efek domino terhadap pihak Bank, karena pembeli dalam membeli objek yang dimaksud telah mencairkan pinjaman di Bank dengan jaminan Sertipikat Hak Milik No. 4144 Kel. Gunung Sarik tersebut dengan berdasarkan kepada covernote yang dikeluarkan oleh Notaris.

Terhadap kasus diatas, Kantor Pertanahan Kota Padang tidak melakukan teguran ataupun sanksi terhadap PPAT yang bersangkutan, hanya melakukan pengembalian berkas karena tidak dapatnya dilanjutkan proses dan pemanggilan secara langsung terhadap PPAT yang bersangkutan untuk diberika teguran secara lisan. Padahal dalam lampiran Peraturan Menteri Agraria dan Tata Ruang/Kepala Badan Pertanahan Nasional Nomor 2 Tahun 2018 tentang Pembinaan dan Pengawasan Pejabat Pembuat Akta Tanah sanksi yang diberikan seharusnya adalah teguran tertulis.

\section{Faktor Penghambat Kepala Kantor Pertanahan Kota Padang Dalam Pengawasan dan Pembinaan Terhadap Pejabat Pembuat Akta Tanah.}

Pelaksanaan pembinaan dan pengawasan terhadap tugas PPAT oleh Kepala Kantor Pertanahan masih kurang optimal yaitu kurangnya pengawasan yang berkesinambungan terhadap PPAT dikarenakan jumlah PPAT yang mencapai 150 orang sehingga tidak terpantu secara menyeluruh.

Sebagaimana disebutkan pada Pasal 1 Peraturan Kepala Badan Pertanahan Nasional Nomor 1 Tahun 2006 tentang Pejabat Pembuat Akta Tanah, bahwa PPAT adalah pejabat umum yang diberi kewenangan untuk membuat akta-akta otentik mengenai perbuatan hukum tertentu mengenai hak atas tanah. Sedangkan Bapak Akmil Ahmad, selaku staf pada Subsi Pemelihraan 
Data Hak Tanah dan Pembinaan PPAT menyebutkan bahwa PPAT adalah pejabat yang berwenang membuat akta untuk peralihan hak atas tanah, akta untuk pemberian hak tanggungan serta melakukan pengurusan layanan pada Kantor Pertanahan Kota Padang yang tidak berkaitan dengan akta seperti pengurusan hapusnya hak tanggungan (roya), perubahan hak, permohonan pensertipikat tanah, permohonan pengukuran dan layanan lainnya. Dalam hal ini, peneliti berpendapat salah satu faktor penghambat adalah kurang memahaminya staf pada subsi yang tugas pokok dan fungsinya melakukan pembinaan dan pengawasan terhadap PPAT.

Kepala Kantor Pertanahan Kota Padang dalam melaksanakan tugasnya juga terhambat terkait dengan peraturan perundang-undangan yang mengatur mengenai tugas, fungsi dan kewenangan Kepala Kantor Pertanahan yang saling bertentangan, ditambah lagi bahwa Kepala Kantor Pertanahan yang telah memberikan teguran lisan ataupun teguran tertulis kepada PPAT yang tidak melaporkan akta dan terlambat menyampaikan akta ke Kantor Pertanahan seakanakan tidak dihiraukan oleh PPAT karena sanksi yang tidak tegas dan terkesan ringan dari aturan yang mengatur tentang kinerja tidak dijalankan dengan baik.

Kerjasama yang kurang harmonis antara PPAT dengan Kantor Pertanahan Kota Padang menyebabkan sulitnya untuk mengadakan pembinaan dan pengawasan PPAT dalam hal penyampaian akta, penyampaian laporan, penyampaian petunjuk pelaksanaan tugas PPAT atau penyampaian peraturan-peraturan ataupun kebijakan-kebijakan terbaru yang berlaku pada Kementerian Agraria dan Tata Ruang/Badan Pertanahan Nasional. Selain ini Kepala Kantor Pertanahan hanya melakukan pengawasan melalui dokumen atau laporan yang dilaporkan oleh PPAT sehingga data yang diperoleh tidak akurat untuk mengetahui pelanggaran-pelanggaran yang dilakukan oleh PPAT dalam pembuatan dan pendaftaran hak atas tanah.

\section{Jenis Pelanggaran Terhadap Kinerja Pejabat Pembuat Akta Tanah}

Dalam pelaksanaan pembinaan dan pengawasan terhadap PPAT yang dilakukan oleh Kepala Kantor Pertanahan Kota Padang dalam pemeriksaan mengenai pelaksanaan kewajiban operasional PPAT khususnya kewajiban PPAT terkait pengiriman laporan akta yang telah dibuatnya setiap tanggal 10 bulan berikutnya dan penyampaian akta lebih dari 7 (tujuh) hari kerja untuk didaftarkan ke Kantor Pertanahan. Jumlah Pejabat Pembuat Akta Tanah wilayah kerja Kota Padang sebanyak 150 (seratus lima puluh) orang. Dalam hal kewajiban pengiriman laporan bulanan terdapat keterlambatan penyampaian akta rata-rata 10 sampai 15 orang PPAT setiap bulannya.

Menurut keterangan Roza Arifin selaku staf pada Subseksi Pemeliharaan Data Hak Tanah dan Pembinaan PPAT, sudah dilakukan teguran kepada PPAT yang terlambat dalam menyampaikan laporan bulanan, akan tetapi setiap bulannya masih saja ada PPAT yang terlambat menyampaikan laporan bulanan tersebut. Teguran yang diberikan adalah teguran tertulis dari Kepala Kantor Pertanahan Kota Padang, dan teguran tersebut tidak diteruskan ke Majelis Pembina dan Pengawas Daerah maupun Mejalis Pembina dan Pengawas Wilayah sehingga terkesan PPAT mengabaikan teguran yang diberikan. 
Dalam hal keterlambatan penyampaian akta yang dibuat oleh PPAT, berdasarkan data pada situs Kementerian Agraria dan Tata Ruang/Badan Pertanahan Nasional https://statistik.atrbpn.go.id terdapat lebih kurang $20 \%$ keterlambatan penyampaian akta setiap bulannya. Untuk kegiatan layanan Hak Tanggungan sudah diminalisir dikarenakan telah menggunakan hak tanggungan elektronik sehingga keterlambatan dapat dipantau langsung oleh Kepala Kantor Pertanahan, MPPD, MPPW serta MPPP. Sedangkan untuk kegiatan peralihan hak belum ada pengawasan ataupun penolakan terhadap akta yang terlambat didaftarkan.

Menurut keterangan Bapak Akmil Ahmad selaku staf pada Subseksi Pemeliharaan Data Hak Tanah dan Pembinaan PPAT, keterlambatan penyampaian akta inilah yang sangat bereriko besar dalam timbulnya permasalahan pertanahan. Misalnya adanya gugatan atau pemblokiran yang masuk dalam rentang tanggal pengecekan sertipikat dan tanggal didaftakannya akta peralihan ke Kantor Pertanahan, yang dapat merugikan para pihak ataupun pihak lain yang berkepentingan dalam layanan peralihan hak tersebut.

\section{Sanksi Terhadap Pelanggaran Yang Dilakukan Oleh PPAT}

PPAT dalam melaksanakan tugasnya wajib mengikuti aturan, ketentuan-ketentuan sebagaimana dimaksud dalam pasal 38, pasal 39 dan pasal 40 Peraturan Pemerintah Nomor 24 Tahun 1997 tentang Pendaftaran Tanah, serta ketentuan dan petunjuk yang diberikan oleh Kementerian Agraria dan Tata Ruang/Badan Pertanahan Nasioanl atau pejabat yang ditunjuk dikenakan tindakan administratif berupa teguran tertulis sampai pemberhentian dari jabatannya sebagai PPAT, dengan tidak mengurangi kemungkinan dituntut ganti kerugian oleh pihak-pihak yang menderita kerugian oleh pihak yang diakibatkan oleh diabaikannya ketetnuan-ketentuan tersebut.

Selanjutnya dalam peraturan jabatan PPAT yang tertuang dalam Peraturan Kepala Badan Nomor 1 Tahun 2006 tentang Pejabat Pebuat Akta Tanah yang dipertegas lagi dalam ketentuan Peraturan Menteri Agraria dan Tata Ruang/Kepala Badan Pertanahan Nasional Republik Indonesia Nomor 2 Tahun 2018 tentang Pembinaan dan Pengawasan Pejabat Pebuat Akta Tanah, disebutkan bahwa pemberian sanksi yang dikenakan terhadap PPAT yang melakukan pelanggaran dapat berupa:

1. teguran tertulis

Pemberian sanksi dengan teguran tertulis terhadap pelanggaran yang dilakukan oleh PPAT dilakukan oleh Kepala Kantor Pertanahan wilayah kerja PPAT tersebut.

2. pemberhentian sementara

Pemberian sanksi dengan pemberhentian sementara terhadap pelanggaran yang dilakukan oleh PPAT dilakukan oleh Kepala Kantor Wilayah Badan Pertanahan Nasional.

3. pemberhentian dengan hormat

Pemberian sanksi dengan pemberhentian dengan hormat terhadap pelanggaran yang dilakukan oleh PPAT dilakuka oleh Menteri. 
4. pemberhentian dengan tidak hormat

PPAT diberhentikan dengan tidak hormat dari jabatannya dapat dikarenakan melakukan pelanggaran berat terhadap larangan atau kewajiban sebagai PPAT atau dijatuhi hukuman kurungan/penjara karena melakukan kejahatan perbuatan pidana yang diancam dengan hukuman kurugan atau penjara selama-lamanya 5 (lima) tahun atau lebih berat berdasarkan putusan pengadilan yang sudah berkekuatan hukum tetap. Pemberian sanksi dengan pemberhentian dengan hormat terhadap pelanggaran yang dilakukan oleh PPAT dilakukan oleh Menteri.

\section{PENUTUP}

Dampak pembinaan dan pengawasan terhadap Pejabat Pembuat Akta Tanah (PPAT) wilayah kerja Kota Padang oleh pejabat Kantor Pertanahan Kota Padang adalah terciptanya tertib administrasi. Pembinaan dan pengawasan belum berjalan dengan maksimal sehingga masih ada PPAT yang melakukan pelanggaran dan terkesan mengabaikan sanksi yang telah diberikan. Terhadap PPAT yang melakukan pelanggaran atau kelalaian, Kepala Kantor Pertanahan memberikan sanksi berupa teguran tertulis dan teguran tidak tertulis atau lisan sebagaimana yang telah diatur dalam Peraturan Menteri Agraria dan Tata Ruang/Kepala Badan Pertanahan Nasional Nomor 2 Tahun 2018 tentang Pembinaan dan Pengawasan pejabat Pembuat Akta Tanah. Hambatan dalam pelaksaaan pembinaan dan pengawasan PPAT oleh pejabat Kantor Pertanahan Kota Padang adalah waktu dan anggaran. Upaya yang dilakukan oleh Kantor Pertanahan Kota Padang khususnya Subseksi Pemeliharaan Data Hak Tanah dan Pembinaan PPAT adalah selalu melakukan sosialisasi ketika pelaksanaan pelantikan PPAT, melakukan pengawasan dan pembinaan secara maksimal, menjalin komunikasi baik formal maupun informal dengan PPAT guna tercapainya maksud dan tujuan dari pengawasan dan pembinaan.

Disarankan kepada Kantor Pertanahan Kota Padang untuk dapat mengupayakan fasilitasfasilitas penunjuang bagi terselenggaranya secara maksimal pembinaan dan pengawasan terhadap PPAT di wilayah kerja Kota Padang. Selain itu Kantor Pertanahan Kota padang juga harus berkolaborasi dengan pemerintah daerah setempat untuk menyatukan program kerja mengenai pelaksanaan pembinaan dan pengawasan terhadap PPAT sehingga nantinya harapan tercapainya profesi PPAT yang baik dan mulia dapat terealisasi sebagaimana yang diharapkan. Membuat sebuah program penjadwalan yang sitematis dan berkelanjutan yang dilakukan oleh Kantor Pertanahan Kota Padang mengenai pelaksanaan pembinaan dan pengawasan kepada Pejabat Pembuat Akta Tanah di wilayah kerja Kota Padang. Agar tujuan dan maksud dari pembinaan dan pengawasan terhadap PPAT dapat tercapai secara maksimal sebagaimana perintah dan amanah peraturan perundang-undangan berlaku yang mengatur tugas pokok dan fungsi Pejabat Pembuat Akta Tanah. 


\section{DAFTAR PUSTAKA}

Ali Achmad Chomzah, Hukum Agraria (Pertanahan Indonesia) Hukum Pendaftaran Tanah dan KePPATan, Jilid 2, Prestasi Pustaka Pulisher, Jakarta, 2004.

Boedi Harsono, Huku Agraria Indonesia, Sejarah Pembentukan UUPA, Isi dan Pelaksanaannya, Djambatan, Jakarta, 2005.

Effendi Perangin, Hukum Agraria di Indonesia, Rajawali Pers, Jakarta, 1991.

Hutagalung,dkk, Kewenangan Pemerintahan di Bidang Pertanahan, Raja Grafindo Persada, Jakarta, 2008.

Peraturan pemerintah Nomor 24 Tahun 1997 tentang Pendaftaran Tanah.

Peraturan Menteri Agraria dan Tata Ruang/Kepala Badan Pertanahan Nasional Nomor 2 Tahun 2018 tentang Pembinaan dan Pengawasan Pejabat Pembuat Akta Tanah.

Probo Pribadi S.M, Peran Pejabat Pembuat Akta Tanah di Indonesia, diakses dari http://probopribadisembiringmeliala.blogspot.co.id/2013/10/jurnal-hukum-peran-pejabatpembuat-akta.html. 